\title{
Slavistické stretnutie na Novom Zélande
}

\author{
Jana Bujnáková (Brno)
}

25. 8. 2018 sa na pôde Victoria University of Wellington (Nový Zéland) uskutočnila konferencia The Boundries of European National Literatures. Stretnutie organizoval slavista a historik Alexander Maxwell, ktorý pôsobí na School of History, Philosophy, Political Science \& International Relations na tamojšej univerzite. Ten, hoci pochádza zo Spojených štátov, špecializuje sa na slavistiku a v našom geografickom regióne nielenže získal titul Mgr. (Central European University Budapešt'), ale tiež sa sem, za účelom štúdia prameňov a kvôli udržiavaniu kontaktov, pravidelne vracia. Masarykovu univerzitu pracovne navštívil aj v októbri 2017, kedy si pre odbornú verejnost pripravil prednášku Sorbian and the Slavic World: Taxonomy and Imitation.

Hlavnou myšlienkou konferencie bola snaha definovat hranice národov v literatúre a zamerat̉ sa na odlišnosti vnímania hraníc jednotlivými národmi. Pozornost' sa tiež upierala na rozdielny vnútorný a vonkajší pohlad medzi národmi. Dôraz sa kládol aj na zistenie, aké faktory výskum ovplyvňujú na pozadí patriotizmu a národných literatúr. Proces vedie k zachovávaniu dôležitých momentov pre d’alšie generácie, dokumentuje sa umenie, uchovávajú sa spomienky na národných hrdinov. Udržujú, podporujú a vytvárajú sa nové národné tradície. Ale čo to vlastne znamená hranica národa? A. Maxwell sa inšpiroval Benedictom Andersonom, podla ktorého je národ „zo svojej podstaty obmedzeny“. Jedno zo zamyslení stálo na myšlienke, že i národ, ktorý má literatúru definovanú národným jazykom, môže mat̉ nejasne určené hranice. Na to pôsobí viacero faktorov, o. i. dialekty, alebo naopak, internacionalizácia. Na vnímanie tak vplýva zameranie sa na detail, alebo pohlad z vonku, ako celok. Konferencia mala byt akýmsi pokusom definovat hranice národného jazyka, čo je zvyčajne ovplyvnené viacerými faktormi. Môže to byt’ sám autor, literárna skupina, (domáca) literárna tradícia, ale takisto môže názory formovat' okruh vlastencov.

A. Maxwell vystúpil s príspevkom Jan Kollár's Panslavism and the Borders of Slavic Literatures, v ktorom pojednával o hraniciach slovanských literatúr so zretel’om na dielo Jána Kollára. Vychádzal z Kollárom navrhovaných štyroch základných kmeňov slovanského nadnárodného celku s vlastnými jazykmi (ruský, československý, polský a ilýrsky jazyk). Upozornil však aj na Jána Herkela ako autora termínu panslavizmus. Problematike sa venoval aj z lingvistického pohladu. Dennitza Gabrakova sa zaoberala dielom bulharskej spisovatel'ky Kapky Kassabovej, ktorá i ked' nežila vo vlasti, neustále sa zaoberala hranicami Bulharska, z pohladu aj histórie, aj prítomnosti. Autorka realizovala daný výskum s ohladom na dôležitost̉ angličtiny, pretože si uvedomuje znevýhodnené postavenia krajín kvôli možnej izolovanosti jednotlivých národných jazykov. Richard Millington cez dielo Leopolda von Sacher-Masoch demonštroval, že nie vždy je možné uplatnit model založený na priamom pôsobení jazyka a národa navzájom. Kontrast známeho, rešpektovaného a úspešného „cudzinca“ žijúceho a písuceho v Nemecku, hoci Ukrajina i Rusko ho vnímajú ako „svojho“, bol vhodne zvolený ako príklad na preukázanie úvodného tvrdenia. Antonella Sarti Evans vystúpila s komparatívnym príspevkom (talianska literatúra) a sústredila sa na otváranie hraníc domovskej krajiny voči anglofónnemu svetu, a to na základe lásky, priatel'stva a vlastenectva. Charlotte Simmonds sa zamýšlala, akú rolu hrá vonkajšie pozorovanie pri vytváraní národných hrdinov a prostredníctvom I. P. Pavlova a G. E. Sukhareva skúmala, do akej miery Západ uznáva ruskú vedu v rámci vyjadrenia vlastenectva vo vedeckých textoch počas obdobia stalinizmu. Súčasne poukázala 
na zložitú otázku vlastenectva a nacionalizmu (horná x spodná čast’ spoločnosti si môže vybrat vlastnú národnú ikonu). Marco Sonzogni vychádzal z básne Pio (Primo Levi: Ad ora incerta, 1984, s. 589), ktorá podla autora dokáže svojou silou zmenit tradičné predstavy vola ako symbolu mierovej a trpezlivej moci. Popritom autor špekuloval aj o sile prekladu v súvislosti s ovplyvňovaním a posúvaním hraníc národných literatúr. Brniansky Ústav slavistiky na konferencii reprezentovala Eliška Gunišová a autorka tejto správy s komparatívnymi príspevkami zameranými na česko-slovenské vztahy na konci 19. storočia, so zretel’om poukázat na rozdielne vnímanie problematiky na obidvoch stranách, ale súčasne boli prezentované aj spoločné prieniky v súvislosti s národnými a literárnymi „hranicami“.

Pozitívnym zistením je tiež fakt, že univerzita tak d'aleko od slovanského sveta sa venuje slovanským jazykom i literatúram a študenti, a to nielen dennej formy, ale aj $\mathrm{v}$ rámci univerzity tretieho veku, majú záujem vzdelávat sa v tejto oblasti. Opakovane navštevujú organizované kurzy, ktoré na seba vzájomne nadväzujú. Celkovo bolo pracovne velmi motivujúce ocitnút sa na druhej strane sveta, nadviazat vztahy s kolegami z mimoeurópskych pracovísk a diskutovat o odbornej problematike z tzv. pohladu „zvonku“. Reakcie publika, ktoré malo znalosti z danej problematiky, boli vel'mi živé, čo viedlo k zanietenej, plodnej a celú konferenciu sprevádzajúcej diskusii. Prekvapujúce bolo zistenie, ako hlboko siahajú vedomosti jednotlivých odborníkov, ktorí sa slavistike venujú, ale nežijú v danom prostredí. Predmet ich výskumu je do istej miery stažený, lebo nemajú jednoduchý prístup k primárnym materiálom. Na druhú stranu vidia problematiku z inej, pre nás často novej perspektívy, pretože nie sú ovplyvňovaní vnútorným prostredím a situáciou v ňom. Bez ohladu na to, z akého pohladu sa človek nad problematikou zamýšla, každý záver vedie k úvahe, že v rámci sústavného skvalitňovania realizovaného výskumu je nevyhnutné posilňovat spoluprácu so zahraničnými inštitúciami a pracovníkmi a realizovat spoločné projekty, aby dochádzalo ku paralelám, ktoré prinesú nové zistenia.

\section{Mgr. Jana Bujnáková}

Ústav slavistiky

Filozofická fakulta, Masarykova univerzita

Arna Nováka 1, 60200 Brno, Česká republika

bujnak.jana@gmail.com 